\title{
REFORM OF THE IRISH CENSUS OF POPULATION.
}

\author{
By Proferssor C. H. Oldham, President.
}

[Read before the Society on Thursday, 3rd December, 1925.]

The subject of this second Presidential Address which I have the honour of delivering to this Society was suggested by the circular letter (September 10, 1925) in which the Department of Local Government and Public Health announced that it had been authorised by the Executive Council to take a Census of the Population of the Irish Free State in April, 1926. It is fortunate and gratifying that the Government of Northern lreland is also making arrangements to take a Census of their six counties on or about the same date. It ought, therefore, to be possible by a combination of these two Censuses to obtain niost of the figures for an All-Ireland Census, which would make practicable a comparison of the 1926 figures with the figures of the eight previous Censuses since 1841 .

The Minister, by the said letter, has invited the co-operation of this Society (among many others) in determining both the information to be collected and the classifications under which it should be published. The new Council of this Society, elected at our last meeting, has since appointed a standing SubCommittee for the purpose of assisting the said Department until the work upon this new Census has been completed. That Sub-Committee will welcome the co-operation which any member of this Society may be willing to offer to them in this behalf. But, of course, while "prepared to consider" any advice or suggestions which either we or others may be able to give, the Department must alone decide whether the suggested innovations are both feasible and desirable, or shall be ultimately adopted. It is clear that the Department has the ambition to make this first Census of the Irish Free State a success; it is certain that the permanent officials who now administer all our Departments include many men of proved high capacity: we 
may feel confident that their united team-work upon this national undertaking will result in a noble service for all citizens in this country.

Having mentioned this matter, however, I resume my present paper, which is addressed to the members of this Society and is not directed even obliquely to the Department. I want to utilise the coming Irish Census in order to awaken afresh your interest in Irish Statistics. I ask here for a free space to discuss the reform of the Population (ensus of Ireland in the region of ideas, and (if I be fortunate) to send your minds

Voyaging through strange seas of Thought unknown! -to misquote Wordsworth's famous line.

The hest account of the history of the Irish Census is to be found in the "Journal" of this Society, dated December, 1911, which preserves a paper by Sir William J. Thompson, M.D., Registrar-General for Ireland, entitled "The Development of the Irish Census and its National Importance." I here pass over the Censuses of 1821 and 1831. In many respects the famous Census of 1841 created " a new era in Irish Statistics," and became the model subsequently followed: $(a)$ A Census Commission then first appointed ad hoc; $(b)$ Ordnance Survey Maps first used to define the boundaries and to fix the orthography; (c) the Irish Constabulary (created 1837) available for the first time as enumerators; $(d)$ originated the Family Form, to be filled up by Head of Family on Census Night; $(e)$ originated the Irish "Housing Classification"; $(f)$ originated the "Irish Classification of Occupations," so much praised by Mr. Charles Booth and foreign statisticians, but suppressed after 1871 for the sake of British uniformity; etc. Many additional subjects of inquiry were added to the Irish Census subsequent to 1841 which were not dealt with in England and Scotland. Thus, in 1851 we had $(g)$ School Census, $(h)$ Statistics of Diseases and Infirmities, (i) Agricultural Statistics. In 1861 we had, again for Ireland only, $(j)$ Religious Professions counted. In 1871 we had (besides the change about "Occupations") (k) Shipping Census, $(l)$ two volumes on Vital Statistics (first collected for Ireland from 1864), and ( $m$ ) County Books were first issued. In 1881, besides $(n)$ the first detailed account of the tad social conditions in the Dublin Registration Area, we had (o) the introduction of the tremendous Irish Land Census (Agricultural Holdings). The 1891 Census is the only one which had no novelties. The 1901 Census was a new departure, because the Local Government Act, 1898, had considerably 
altered the territorial sub-divisions of the country; and this Census is $(p)$ an important link relating the older divisions (Geographical Counties, Baronies, Civil Parishes, Ecclesiastic Dioceses, etc.) with the newer divisions (Administrative Counties, District Electoral Divisions, Poor Law Unions, Dispensary or Registration Districts, etc.) through the medium of the Townland Census. The only novelty at the 1911 Census was (q) a "Special Inquiry into Marriages and the Number of Children per Marriage."

This survey of the growth of the Irish Census since 1841 (in directions not followed in the Census for England or for Scotland) may be exhausting to read and to comprehend; although it is certainly not exhaustive of the innovations themselves. But it is put in here with the direct object of suggesting a reform. My own opinion is that the Irish Population Census has become too much elaborated, that it includes far too many subjects which rightly should not form part of the Population Census at all (or only in a briefly-summarised form, for convenience of reference). I shall go into details later on. Here I merely make the point that we might well drop a big lot.of subjects which have become less important.

I accept the principle laid down by Sir William J. Thompson in 1911 :- " The inquiries of a Census should lead to improvements being effected for the population under each of the various headings, such as education, house accommodation, industrial occupations, etc., and it may be laid down as a principle that no inquiry is worthy of being included in a Census Schedule unless it has for its object the eliciting of some facts of wide material interest, needed to bring out the social and economic character of the people."

It must have been noticed that the taking of the New Census by a polygenous Department, in the place of a Commission empowered and instructed ad hoc by a special Act of the Legislature, is already an innovation of gigantic proportions. I am only here concerned with the statistical effect of this change. Let me tabulate the personnel of previous Irish Census Commissions:

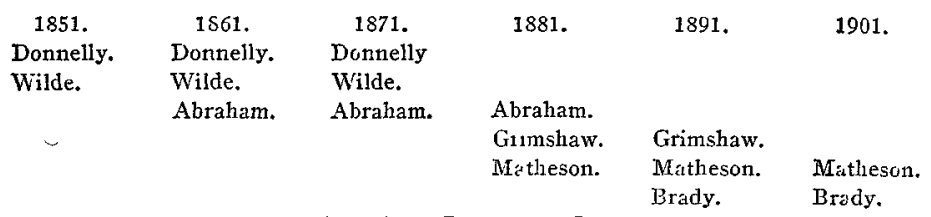


It is obvious that a continuity in the personnel was carefully preserved. Now in regard to statistics, continuity is of much more importance than accuracy, because statistics have to be comparable before they can mean anything. However, the Department can itself commit the performance of its task to a suitably-chosen body of experienced statisticians. Danger is only to be feared if the Ministry should start with an idea that it had a free hand to take this first Census upon what may seem to be ideally-perfect lines without having strict regard to the imperative principle of continuity. The danger (in that very improbable case) is that the offspring of its labour should be still-born: in plain words, its statistical output might be worthless and the work would have to be done over again.

I have in mind what happened with the Irish Agricultural Statistics for 1900, when they were taken over from the Office of the Registrar-General and were issued for the first time by the new Department of Agriculture and Technical Instruction. Dr. W. P. Coyne, thinking that he had a free hand, ventured in his first Report (Cd. 557 of 1901) to alter the previous classification for "arable" and "pasture" lands. He took "Hay mown on permanent pasture" and "temporary grasses" when grazed, and these were (as he said) "put in the category of Grass (though technically, of course, as being under rotation, the latter is a crop)." His idea was to ascertain the employment aftorded by tillage, and therefore to more accurately "distinguish land under the plough from land given over to stockraising"--and it was an excellent idea. But the result was disastrous, because he did it in a way which destroyed the continuity of the figures. As there was a new report next year, that mistake could be rectified at once; and in his second Report (Cd. 1170 of 1902) we find a table inserted which preserved the continuity of the classification which had existed from 1847 down tc 1899. Finally, after Dr. Coyne's lamentably early decease, his successors, Mr. Thomas Butler (issuing as locum tenens Cd. 2196 of 1904) and Mr. W. G. S. Adams (whose first Report was Cd. 2722 of 1906) restored the classification to its old comparable form. For, as Mr. Adams wrote, we cannot avoid in Ireland "a certain indefiniteness with regard to the terms arable and pasture land, owing to the intermediate position which is held by hay."

This small point is only referred to here as an illustration of this important principle : that while innovations are sometimes allowable, care must be taken at the time the innovation is made to preserve also the continuity of the statistics in the form comparable with previous years. I may be allowed here 
to refer to my Presidential Address of last year on "The Interpretation of Irish Statistics," which is preserved in the "Journal " of this Society dated October, 1925. While I maintain that in this matter of statistics innovations are extremely perilous, this is not to say that innovations are barred out. But when an innovation is deemed desirable it ought to be made as an addition, not as a substitute. The success of the coming Census will statistically depend on the firmness with which innovations are resisted and vigorously kept down to the minimum.

By innovation I mean, of course, a new way of presenting the figures of an old subject that is still retained in our Census. The complete omission from our New Census of subjects, vhich have either lost their former importance or else which can to-day be better handled outside of a Population Census properly so called, is another thing entirely. That is a change that I think is long overdue with the Irish Census of Population. In this connection I will now consider four large sections of this publication: (I.) Religious Professions, (II.) Education, (III.) the formidable Land Census (Agricultural Holdings), and (IV.) Occupations of the People. Only the last named of these four finds place in the Census for England or for Scotland.

(I.) The Religious Professions section of the Irish Census had great political value in former days when the Irish Roman Catholics were suffering from heavy civil and religious disabilities. It is very significant that it first appeared as a section of our Census in 1861; and that the Disestablishment of the Frotestant Episcopal Church followed in the Act of 1869. That Act, together with the Land Purchase Acts, laid the foundations of National Unity in Ireland. To-day all sections of the Irish population stand equal before the Law, and the political aspect of statistics of Religious Profession is no longer a factor in Irish life. On the other hand, the religious aspect of those statistics is very important; and, in the provision of separate school accommodation for separate Churches, it may be thought to touch on State functions. But for religious purfoses such Statistics could be much better done by each Church for its own members, possibly with a State subsidy towards defraying the expense. The real test of religion is not outviard profession, but the exercise of the spiritual life in prayer. Flow ridiculous it would be to ask a police enumerator to collect statistics on the subject of Prayers in Irish life, or of Confession, or of any other act of genuine religion such as attendance at Church Service! If there is to be a "religious" census 
it ought to be such as would help to the deepening of spiritual life. The statistics collected in the Rejigious Section of the Irish Census are obsolete for political purposes, useless for purpcses of true religion, and injurious socially as accentuating partisan rancours between separate Christian Sects. A real Census of Religion, taken by the Churches themselves, not by the Government enumerators, would be a stern reality: incidentally it would reveal the large numbers of the population who were not in contact with any of the organised Churches, and it would show the great field for missionary effort which exists within our own home borders. Let us not abolish the Census of Religion; but let us take it out of the Census of Population.

(II.) What taking a thing out of the Census of Population means in practice can be better illustrated by the School Census taken with the Irish Census since 1851. Not only was information collected as to illiteracy, but also a Form was issued to Schools and Colleges to be filled up by the Head Master. This Education Form did not apply to the Census Night (e.g., April 2nd); it applied to two complete weeks in May. Attendance or non-attendance during each of these weeks is marked by "Yes" or "No." Then the subjects studied by each scholar was indicated, there are separate columns headed Latin, Greek, Mathematics, Modern Languages, Irish, etc. Now it is obvious that this elaborate Education Census might be taken altogether apart from the Population Census; it might be taken ad hoc by the Ministry of Education and brought out by its own Inspectors at any time when that Ministry wanted the information. By the Education Department actually taking its own Education Census, and by keeping for its own office use the Forms so filled up, this Census would directly influence the administrative efficiency of that Education Department itself (through which alone reforms in Educational Policy can come) far nore tilan when it is taken as a part of the Population Census. In any case, this Education Census ought to be available for the Schools as an independent publication.

(III.) Again, there is that huge section of the Irish Census called the "Land Census," giving the numbers of Agricultural Holdings under 12 Classes, according to the rateable valuation, and under 11 Classes, according to size by acreage; for Ireland, for each Province, for each County, for each Poor Law Union; with the actual numbers of Holdings of each Class reduced to the percentage of each County's total area, etc., with their Resident Population, with their Housing Accommodation, with their Out Offices, and so on-ad infinitum. This amazing 
example of statistics gone crazy fills about 190 pages of the General Report of our Population Census, where it smothers everything else, and turns every reader sick. It is really of great economic value. But nobody wants it beyond a few offcials in the Estates Commission or the Land Ministry and a very few students of Irish Economics. It also ought to be an independent publication; and it ought to be got out, only at wide intervals, by the Department of Lands and Agriculture, employing on this job the same enumerators who annually collect the Agricultural Statistics Anyhow, it has no right to a place in the Population Census no more than has a Census of Production for Industry and Agriculture. Its presence in the Population Census is a statistical deformity, which frightens off readers by its indigestible bulk and which adds enormously to the selling price of the publication.

(IV.) There remains for consideration that complicated section of the Census called "Occupations of the People." In $\epsilon$ very country this is a most difficult part of the Census to handle in a useful way. 'The information is most valuable if it can be got. But it is not got, with any approach to precision, by any of the methods yet adopted by any country with which I am acquainted. Very similar information might well be collected by quite a different method during the compilation of a Census of Production. The Irish Classification of Occupations of 1841 was economically superior to the British Classification, which only came twenty years later. When complying with the Census Act for 1861 (which had prescribed the British scheme for the sake of uniformity) the Irish Census of 1861 also maintained the comparability with 1841 and 1851 by printing the 1861 results according to both Classifications. In 1871 the British Schedule of Occupations was made compulsory; and in the County Books only the British Scheme was allowed to be printed. But in the General Report, by special permission of the Lord Lieutenant, Tables were printed for the last time according to both Classifications-so far as the Irish Classification could be made out from returns collected on the British Schedule. This General Report (C. 1377 of 1876) contains a pasterly examination by the Irish Commissioners of the difficulties attending the subject of statistics for Occupations; which incidentally exhibits the defects of the original British Classification then imposed upon Ireland for good or for bad. Now, at the late British Census of 1921 a wholly new scheme for Classification - both (i) by Occupations, and (ii) by Industries-has been adopted. The English having thereby broken with continuity for the sake of improvement, a difficult case 
arises for Ireland in the coming Census. Are we once more to break continuity with our past, dating back to 1861, by now adopting the new British Classification: which, because it has been designed to fit British industrial conditions, is likely to be a misfit for the very dissimilar industrial conditons of Ireland? I cannot deal with such a large question in my present paragraph. I hope that some member of this Society may be forthcoming to give us a whole paper on the subject. Meanwhile I will say this: Anyone who ever read the remarkable essay by Mr. Charles Booth, which was read to the Royal Statistical Society of London on May 18, 1886 (and which was extended. for Ireland only, for the Financial Relations Commission, viz., 1895, Cd. 7720, Pt. II., page 217), will understand how instructive these Census figures relating to the Occupations of the People can be made when handled by a master statistician. This information ought to continue to be part of the Irish Population Census on the old lines if only to supply some future master in the use of statistics with the materials for bringing Mr. Charles Booth's sombre picture of Ireland's economic decay up to date, when the happier times, that we all hope for as soon to come, will brighten the picture with the glowing colours of Ireland's economic, recovery.

Assume that the Population Census of Ireland were to be reduced in bulk by shoving out into independent publications some of the unwieldly sections which now overload it, the space thereby saved might partly be used to great advantage by a much-needed improvement in the manner of presenting the results to the public. To this aspect of reform I will now ask your attention.

Irish Statistics are hieroglyphics that express chunks of Irish Life to those who can read them. But figures are not scientific evidence to any thinking mind unless one knows by what method the measurement of the massed facts was done We ought to be told that whenever the statistics are published. Even when we can read through the figures to the massed facts that stand behind them, we must then proceed to the next step of interpreting, of perceiving the significant meaning of what we are told. It is ridiculous to merely fling down figures, in the traditional British manner, without supplying the public with all the information needed in order to interpret the meaning of the statistics. Now, just here is where the opportunity lies waiting for the Department of Local Government and Public Health to make a distinguished new departure for the first Census of the Irish Free State. Let it put all its capacity into the task of interpreting the statistics that it publishes. 
I take, as illustration, a Table which has appeared in every Irish Census since 1841 : it is Tahle 43 on page 62 of the 1911 Census (Cd. 6663 of 1912-13, Vol. CXVIII.). It states the actual numbers of the sexes in each Province of Ireland, as 1eturned at each Cersus. Nobody has read this Table as printed, for it cannot be interpreted, until recalculated to show the relative numbers of the sexes. When translated to show the number of Females per 1,000 Males, this Table will be seen to be sensationally interesting, viz. :-

\begin{tabular}{|c|c|c|c|c|c|c|c|c|c|}
\hline \multicolumn{10}{|c|}{ FEMALFs PER 1,000 MaLes. } \\
\hline Census. & Leinster. & & Munster. & & Connaught. & & Ulster. & & Treland. \\
\hline 1841 & 1048 & $\ldots$ & 1020 & $\ldots$ & 1004 & ... & 1054 &. & 1034 \\
\hline 1851 & 1056 & $\cdots$ & 1053 & $\cdots$ & 1038 & & 1060 & $\ldots$ & 1053 \\
\hline 1861 & 1038 & $\ldots$ & 1032 & $\ldots$ & 1011 & & 1073 & $\ldots$ & 1044 \\
\hline 1871 & 1045 & $\ldots$ & 1031 & $\ldots$ & 1021 & & 1084 & $\ldots$ & 1050 \\
\hline 1881 & 1030 & $\ldots$ & 1017 & $\ldots$ & 1019 & . & 1084 & $\ldots$ & 1042 \\
\hline 1891 & 1021 & $\ldots$ & 995 & $\ldots$ & 1001 & $\ldots$ & 1073 & $\ldots$ & 1029 \\
\hline 1901 & 1016 & .. & 989 & & 999 & $\ldots$ & 1071 & $\ldots$ & 1026 \\
\hline 1911 & 993 & .. & 949 & $\ldots$ & 958 & $\ldots$ & 1052 & $\ldots$ & 1003 \\
\hline
\end{tabular}

N.B-For All Ireland, the Registrar-General estimated $1921=971$.

You now perceive (for the first time?) that Ireland to-day is a country having a Male Surplus. It has been tending that way ever since 1851. This phenomenon appeared first in Munster, it then extended to Connaught also, and it is at last seen also in Leinster. Ulster is an exception, probabiy because in the various branches of its textile industries it offers employment suitable for women. But since 1881 the Ulster figures show the same tendency. The Census Reports ought to have revealed this interpretation of the figures. Furthermore, beside the Irish figures, we ought also be told the European figuresfor in this matter Ireland is unique in Europe. I can only quote here the number (Females per 1,000 Males) for a single date in each case, viz. :-England and Wales $(1921)=1095$; Scotland $(1921)=1079$; Denmark $(1911)=1060$; Sweden $(1913)=$ 1045 ; Norway $(1910)=1069$; Holland $(1913)=101.3$; Portugal $(1911)=1100$; German Reich $(1910)=1026$, etc. We cannot set the significance of the Irish figures unless we can compare ourselves with Europe. Finally, if we consider only the Adult Population (aged 20 years and up) even the Irish figures undergo a curious change, viz. :-

\begin{tabular}{cccccccc} 
Census. & Total Adults. & & Male Adults. & & Female Adults. & \multicolumn{2}{c}{$\begin{array}{c}\text { Females per } \\
1000 \text { Males. }\end{array}$} \\
1881 & $2,801,890$ & $\ldots$ & $1,337,516$ & $\ldots$ & $1,464,374$ & $\ldots$ & 1095 \\
1891 & $2,625,775$ & $\ldots$ & $1,264,973$ & $\ldots$ & $1,360,802$ & $\ldots$ & 1076 \\
1901 & $2,632,786$ & $\ldots$ & $1,277,548$ & $\ldots$ & $1,355,238$ & $\ldots$ & 1061 \\
1911 & $2,666,571$ & $\ldots$ & $1,316,898$ & $\ldots$ & $1,349,673$ & $\ldots$ & 1025
\end{tabular}


Did any of you know that the Adult Population of Ireland has been rising since 1891? But it is only a rise of Male Adults : Ireland is not a place where Adult Women can find a living. I notice that the Male Adults who drafted the Civil Service Amendment Bill, which has passed its Second Reading in the Dail recently by a narrow majority, are determined to cust the Adult Women from that form of employment. These men are unable to read the facts of Irish Life because of the bad form in which the Irish Census has been published. They ought to hold their hand until the New Census has been published. The survival of the Irish Race in Ireland depends upon whether we can arrest this disease of the Male Surplus.

In past times the province of an Irish statistician has been to supply just those Irish figures that were needed to complete the totals for the United Kingdom. Then, whenever comparison had to be made with Foreign Countries, the unit for this comparison was never Ireland but always the United Kingdom. (See any issue of the Statistical Abstract for the Principal and Other Foreign Countries; the last, or 39th Number, was Cd. 7525 of 1914.) Hence in our Irish Statistics we have been given none but comparison of Ireland with Ireland herself in previous years. To-day Irish statisticians are proudly conscious that they are the interpreters to other nations of the srcial and economic character of an independent Member of the League of Nations. Hence we may expect to find in the statistical publications of the Irish Free State an habitual use of comparison of Irish figures with the corresponding figures for other European or Dominion countries, which are of the type most suitable for comparison with our own type This will be an absolutely new departure in Irish Statistics; it will carry the minds of the Irish people into regions of thought hitherto unknown to them. I do not mean that their knowledge of other countries will be enlarged by such comparisons; I mean that their knowledge of Ireland itself will dawn for the first time upon their intelligence with a quite novel significance. Nobody can know Ireland who only Ireland knows. The statistical purpose of such international comparisons is to provide the human mind with a norm or standard by which the character of the Irish fact (when reduced to measurement by statistics) can be judged and assigned its peculiar (often very peculiar!) place among the facts of the contemporary world. The outstanding hitherto-unseen truth which Irish Statistics will now reveal to ourselves is that Ireland is amazingly unlike any other country. Her statistics will become the most quoted of all countries because in most statistical generalisations Ire- 
land will be found to be an exceptional case. But nobody in Ireland is yet aware how anomalous we Irish are, unless he has been at the trouble (and it is a very'great trouble) to compare Irish Statistics with the comparable statistics of other countries.

Consider, for example, that best-known of the features in which Ireland is unique-that it alone is a country where population has been dimmishing since 1845 . The accepted explanation to most Irish minds is the one word-emigration. Now emigration is found in every European country; but if countries are compared together and classified according as their emigration is (i) great, (ii) moderate, or (iii) small, it will be seen that for many years past Ireland has belonged to Class (ii), and that for a dozen years back she is found to be in Class (iii). What most Irish people have yet to learn is that in Ireland our births are much too few, our deaths are much toc many; so that our "natural increase" is so small that it fails to fill up the gap caused by a quite moderate emigration. These facts about Irish Life will not be learned except through comparative international statistics. This is the sort of thing that our Irish Statisticians have now got to give us. Let me give you a taste of it, to be going on with. In the next Table I worked out the "natural increase" (excess of Births over Dearhs) for two single years, 1885 and 1910, showing the alterations in these matters after an interval of 25 years. (The figures are taken from the Statistical Abstracts.)

Excess of Birth-Rate over Death-Rate (per 1000).

\begin{tabular}{|c|c|c|c|c|}
\hline Country. & & Single Year, 1885. & & Single Year, 1910. \\
\hline & & B. D. Incr. & & D. Incr. \\
\hline Ireland & $\ldots$ & $23 \cdot 5-18 \cdot 4=5 \cdot 1$ & & $23 \cdot 3-17 \cdot 1=62$ \\
\hline England & $\ldots$ & $325-190=135$ & $\ldots$ & $251-135=116$ \\
\hline scotland & $\ldots$ & $322-191=13 \cdot 1$ & $\ldots$ & $262-15 \cdot 3=109$ \\
\hline Denmark & & $336-18 \cdot 9=147$ & & $27 \cdot 5-12 \cdot 9=14 \cdot 6$ \\
\hline Norway & $\ldots$ & $324-17 \cdot 3=151$ & $\ldots$ & $26 \cdot 1-135=126$ \\
\hline Sweden & $\ldots$ & $303-18 \cdot 4=11 \cdot 9$ & $\ldots$ & $247-140=107$ \\
\hline Switzerland & $\ldots$ & $288-22 \cdot 4=6 \cdot 4$ & $\ldots$ & $250-151=99$ \\
\hline Holland & $\ldots$ & $362-228=134$ & $\ldots$ & $28 \cdot 6-1.3 \cdot 6=15 \cdot 0$ \\
\hline Belgium & $\ldots$ & $31 \cdot 8-21 \cdot 9=99$ & $\ldots$ & $237-15 \cdot 2=85$ \\
\hline Portugal* & $\ldots$ & $32 \cdot 1-23 \cdot 2=89$ &. & $321-191=130$ \\
\hline Spain* & $\ldots$ & $361-32 \cdot 2=39$ & & $33 \cdot 1-23 \cdot 3=9 \cdot 8$ \\
\hline Italy & $\ldots$ & $40 \cdot 1-284=11 \cdot 7$ & $\cdots$ & $323-199=124$ \\
\hline Germany & & $385-27 \cdot 2=11 \cdot 3$ & $\ldots$ & $29 \cdot 8-16 \cdot 2=13 \cdot 6$ \\
\hline ante & ${ }^{\circ}$ & $2 \cdot 3$ & $\ldots$ & $6-1$ \\
\hline
\end{tabular}


In reading this table it is well to recollect that an emigrat1on of 7 per 1000 is "moderate," and of under 4 per 1000 is "small," for European populations. For Ireland, 7 per 1000 means the emigration of over 30,000 persons per annum. Our "natural increase" cannol afford that much. The Irish quota for immigration to the United States under the revised PerCentum Limit Act is 28,567 for 1924-26, of which 2,670 belongs to Northern Ireland.

Of course, the principle which I am elucidating in this table-namely, that Irish ideas about Irish facts would be yreatly corrected if our Irish Statistics, as published, were interpreted by comparisons made with the corresponding figures ior other European countries-will also apply to many matters which lie outside the scope of a Census of Population properly so called. Take the use made of the soil in different countries. The very small use which our people make of one of the most fertile soils in Europe can never be brought home to the intelligences of Irishmen except through international comparisons.

This application of the method has made such a profound rhange in my own views that $I$ ask leave to introduce it here as another example, notwithstanding that Agricultural Statistics are now rightly excluded from our Population Census. I admit that it is a digression. I can, however, shorten the digression if I may refer to my own Paper entitled "Some Perplexities in regard to Agricultural Statistics in Ireland," which was reprinted in the "Journal" of this Society dated October, 1925. I there grouped the acreage figures for the "Divisions of Land " in Ireland by reducing them to percentages of Total Area. Thus, if the Total Area of Ireland $=100$, then in 1911 (as I showed) -
All Crops except Hay ...
Hay, including permanent Meadow
$\ldots=11.6$
$\ldots=124$
$\ldots=61.3$
$\ldots=1.5$
Woods
... $\quad .$.
Non-Agricultural, including Smaller Waters $=13 \cdot 2$

$100 \cdot 0$

Now, assume that the first and second items can be grouped logether and that this "Cropped Land " of Ireland can be called Arable Land (we know, of course, that most of the Hay was "cropped" from Meadows that were not ploughed), and can be represented by $A$. Assume that the third item can be called Pasture Land and represented by $P$. Consider the final item (much of which is very valuable, but it is Non-Agricultural), 
to be called Barren Land, and be represented by $\mathrm{B}$. Then the use of the soil in Ireland can be quantitatively described by the formula $-\mathrm{A}=24.0, \mathrm{P}=61 \cdot 3, \mathrm{~W}=1 \cdot 5$, and $\mathrm{B}=132$; Total $=100 \cdot 0$. When every country in Europe publishing Agricultural Statistics has been described by the similar formula, we are in a position to compare the use made of the soil in different countries. That is what has been done for nine countries in the next Table, to which I ask your attention.

\section{USE of the Soll in Europe.}

(in percentages of Total Area.)

$A=$ Arable. $P=$ Pasture. $W=$ Woods. $V=$ Vinyards $B=$ Barren.

Belgium.

(1)

$$
\begin{aligned}
A & =49 \cdot 1 \\
P & =26 \cdot 0 \\
W & =166 \\
B & =8 \cdot 3 \\
& \frac{}{1000}
\end{aligned}
$$

Italy.

$$
\begin{aligned}
& A=39 \cdot 9 \\
& P=25 \cdot 0 \\
& W=15 \cdot 7 \\
& V=6 \cdot 3 \\
& B=13 \cdot 1 \\
& 100 \cdot 0
\end{aligned}
$$

France.

(7)

$$
\begin{aligned}
A & =52.4 \\
P & =11 \cdot 3 \\
W & =18 \cdot 3 \\
V & =3 \cdot 7 \\
B & =14 \cdot 3
\end{aligned}
$$

Holland.

(2)

$$
\begin{aligned}
A & =27 \cdot 7 \\
\mathrm{P} & =34.7 \\
\mathrm{~W} & =69 \\
\mathrm{~B} & =30 \cdot 7 \\
& =300 \cdot 0
\end{aligned}
$$

Germany.

$$
\mathrm{A}=48.4
$$$$
\mathrm{P}=20.3
$$$$
\mathrm{W}=25 \cdot 7
$$$$
\mathrm{V}=0.3
$$$$
\mathrm{B}=5 \cdot 3
$$

$$
\overline{1000}
$$

Denmark.

$$
\begin{aligned}
A & =42.5 \\
P & =28 \cdot 2 \\
W & =4 \cdot 6 \\
B & =24.7
\end{aligned}
$$

United Kingdom.

(3)

$$
\begin{aligned}
\mathrm{A} & =18.8 \\
\mathrm{P} & =42.7 \\
\mathrm{~W} & =3.6 \\
\mathrm{~B} & =34.9 \\
& =300
\end{aligned}
$$

Switzerland.

$$
\begin{aligned}
& A=16.5 \\
& P=35.9 \\
& W=18.4 \\
& V=0.8 \\
& B=28.4 \\
& 100 \cdot 0
\end{aligned}
$$

Ireland.

(9)

$$
\begin{aligned}
& * \mathrm{~A}=24 \cdot 0 \\
& \mathrm{P}=61 \cdot 3 \\
& \mathrm{~W}=1.5 \\
& \mathrm{~B}=13.2 \\
& \\
& 1000
\end{aligned}
$$

\section{$\overline{1000}$}

*Includes $\mathrm{Hay}=12.4 \%$, mostly off Permanent Meadow.

In this Table the countries are arranged in the order of Population Density per square mile. There is no date, except 
the 1911 assigned to Ireland. But if different dates be calculated the figures will be found to change only slightly, their permanence being due to geographical conditions that alter but slowly. Yet the Great War, by its drain upon the manhood of koth belligerents, has worsened the figures for both Germany and France, and seems to have improved the figures for Switzerland. (See the Appendix, where I have recalculated these three countries for post-war dates.) Ireland which has lost so much population since 1851 is always an exceptional case. The Table brings this out very clearly. The fact that 613 per cent. of Ireland is under Pasture is truly astounding; the nearest case being Switzerland, with Pasture only 35.9 per cent. The 24 per cent. of Ireland represented as "Cropped Land" would be small even if it were all ploughed land; but we know that only 12 per cent. came under the plough-the other 12 per cent. only came under the scythe. The disappearance of Woods from Ireland is painfully in evidence. The small percentage assigned to Barren shows that Ireland is among the most favoured countries in Europe. But this table shows that in no other country is the soil so little worked as in Ireland, unless we go to the barren wastes of Scandinavia. There I must leave it. I hope that the interest of this Table will have excused the digression by which it was brought under your notice.

From the illustrative instances given it has been made clear that, in the matter of the form in which the results of the Census is presented to the public, great improvements are possible. If I am right in my assumption-if the Department be really ambitious to make this first Census of the Irish Free State a notable new departure in Irish statistics, it is certainly In this direction, in the elucidation of the Census figures by interpreting their significance to the public, that all its capacity and enthusiasm should be concentrated. Statisticians sometimes apply the term "secondary comment" for that sort of elucidation of the primary Census figures. To find ample room for a great new extension of such secondary comment, it is absolutely necessary that the Population Census for Ireland should be pruned of a great part of its withered branches, and that some vital parts should be divided from the parent tree in order to take on an independent growth of their own.

It is manifest that the compiling of this secondary comment will take a considerable time, and ought not to be rushed. Eut it has long been the custom to issue a Preliminary Report of the Census with the utmost expedition; and then with adequate deliberation to prepare the Final Report. In the fol- 
lowing Table I have compared these two Reports as regards one single statistic - namely, the "Total Population of Ireland." The number of days between Census Night and the issue of the Preliminary Report is shown in the second column; and the last column shows the error in this one statistic.

\section{Ireland's Population: Preliminaky and Final Figures.}

$\begin{array}{lccccccccc}\text { Census. } & & \text { Days. } & & \text { Preliminary. } & & \text { Final. } & & \text { Error. } \\ 1871 & \ldots & 73 & \ldots & 5,402,759 & \ldots & 5,412,377 & \ldots & +9,618 \\ 1881 & \ldots & 73 & \ldots & 5,159,839 & \ldots & 5,174,836 & \ldots & +14,997 \\ 1891 & \ldots & 53 & \ldots & 4,706,162 & \ldots & 4,704,750 & \ldots & -1,412 \\ 1901 & \ldots & 46 & \ldots & 4,456,546 & \ldots & 4,458,775 & \ldots & +2,229 \\ 1911 & \ldots & 46 & \ldots & 4,381,951 & \ldots & 4,390,219 & \ldots & +8,268\end{array}$

Now, in as much as we all deplore the "partition" of our country, and because it is statistically necessary to preserve comparability with past censuses, I hope that I am right in assuming that the New Census for Ireland that is to be issued by the Irish Free State will be the result of a combination of the two new Censuses for Northern Ireland and for the Irish Free State respectively. In that case the two local Censuses in question will come out in the first instance, like the Preliminary Report of previous occasions; and they will jointly satisfy the superficial requirements which clamour for an expeditious publication of the results of any census. After their appearance, the preparation of the All-Jreland Census, in which all the secondary comment will find its place, can be taken in hand with proper deliberation. If published in the form I have described, in which every All-Ireland statistic would be made comparable with the corresponding statistics for several other European Countries, it is certain that this Population Census of Ireland in 1926 will create a sensation in all parts of Ireland of the greatest magnitude. Its educational value would also be enormous. We really cannot form a correct opinion about any subject of Irish Economics unless we make a study of Irish Life through the difficult language of comparative statistics. Can I speak for this Society as well as for myself? Then, what I would ask the Department of Local Government and Fublic Healih to do with its first Census is to make it a manual of comparative statistics, in order to promote the knowledge of Irish Economics. The People that is unable to properly use statistics is not yet capable of self-government. 
APPENDIX.

Use of the Soil in Post-War Europe.

(By percentage of Total Area).

$\mathrm{A}=$ Arable. $\mathrm{P}=$ Pasture. $\mathrm{W}=$ Woods $. \quad \mathrm{B}=$ Barren.

$\begin{array}{ccc}\text { France. } & \text { Germany. } & \text { Switzerland. } \\ 1920 . & 1922 . & 1921 . \\ \mathrm{A}=41 \cdot 07 & \mathrm{~A}=46 \cdot 9 & \mathrm{~A}=25 \cdot 1 \\ \mathrm{P}=31 \cdot 74 & \mathrm{P}=16 \cdot 3 & \mathrm{P}=25 \cdot 7 \\ \mathrm{~W}=18.75 & \mathrm{~W}=27 \cdot 2 & \mathrm{~W}=20 \cdot 8 \\ \mathrm{~B}=8.44 & \mathrm{~B}=9 \cdot 6 & \mathrm{~B}=28 \cdot 4 \\ \overline{100 \cdot 00} & \overline{100 \cdot 0} & \overline{100 \cdot 0}\end{array}$

From Statistics given in the Statesman's Year Book, 1924. 